\title{
Correction to: Screw fixation in stemless shoulder arthroplasty for the treatment of primary osteoarthritis leads to less osteolysis when compared to impaction fixation
}

Arad Alikhah', Jan-Phillipp Imiolczyk ${ }^{1}$, Anna Krukenberg ${ }^{1}$ and Markus Scheibel ${ }^{1,2^{*}}$

Correction to: BMC Musculoskelet Disord 21, 295 (2020)

https://doi.org/10.1186/s12891-020-03277-3

Following publication of the original article [1], the authors reported the following errors found in the main text.

i) The subpanels found in the legend of Figs. 1 and 2 should be read as "a-h" instead of "a-c".

ii) "Prothesis" is incorrectly spelt in the legend of

Fig. 1. It must be read as "Prosthesis".

iii) The images of Figs. 1 and 2 must be swapped (but not the legends).

The original article [1] has been updated.

Published online: 06 June 2020

\section{Reference}

1. Alikhah A, Imiolczyk J, Krukenberg A, et al. Screw fixation in stemless

shoulder arthroplasty for the treatment of primary osteoarthritis leads to less osteolysis when compared to impaction fixation. BMC Musculoskelet Disord. 2020;21:295 https://doi.org/10.1186/s12891-020-03277-3.

The original article can be found online at https://doi.org/10.1186/s12891020-03277-3.

* Correspondence: markus.scheibel@charite.de

'Department of Shoulder and Elbow Surgery, Center for Musculoskeletal Surgery, Charité-Universitaetsmedizin Berlin, Augustenburger Platz 1, 13353 Berlin, Germany

${ }^{2}$ Department of Shoulder and Elbow Surgery, Schulthess Clinic, Zuerich,

Switzerland

(c) The Author(s). 2020 Open Access This article is licensed under a Creative Commons Attribution 4.0 International License, which permits use, sharing, adaptation, distribution and reproduction in any medium or format, as long as you give appropriate credit to the original author(s) and the source, provide a link to the Creative Commons licence, and indicate if changes were made. The images or other third party material in this article are included in the article's Creative Commons licence, unless indicated otherwise in a credit line to the material. If material is not included in the article's Creative Commons licence and your intended use is not permitted by statutory regulation or exceeds the permitted use, you will need to obtain permission directly from the copyright holder. To view a copy of this licence, visit http://creativecommons.org/licenses/by/4.0/ The Creative Commons Public Domain Dedication waiver (http://creativecommons.org/publicdomain/zero/1.0/) applies to the data made available in this article, unless otherwise stated in a credit line to the data. 